$A \cup T \cup M N$

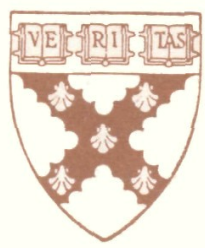

FEATURED IN THIS ISSUE

Who Paid for the LandGrant Railroads?

- Small Manufacturers in World War II

- Scottish Locomotive Building Before 1900

- Charles Schwab and Bethlehem Steel

- EDITOR'S CORNER

BOOK REVIEWS

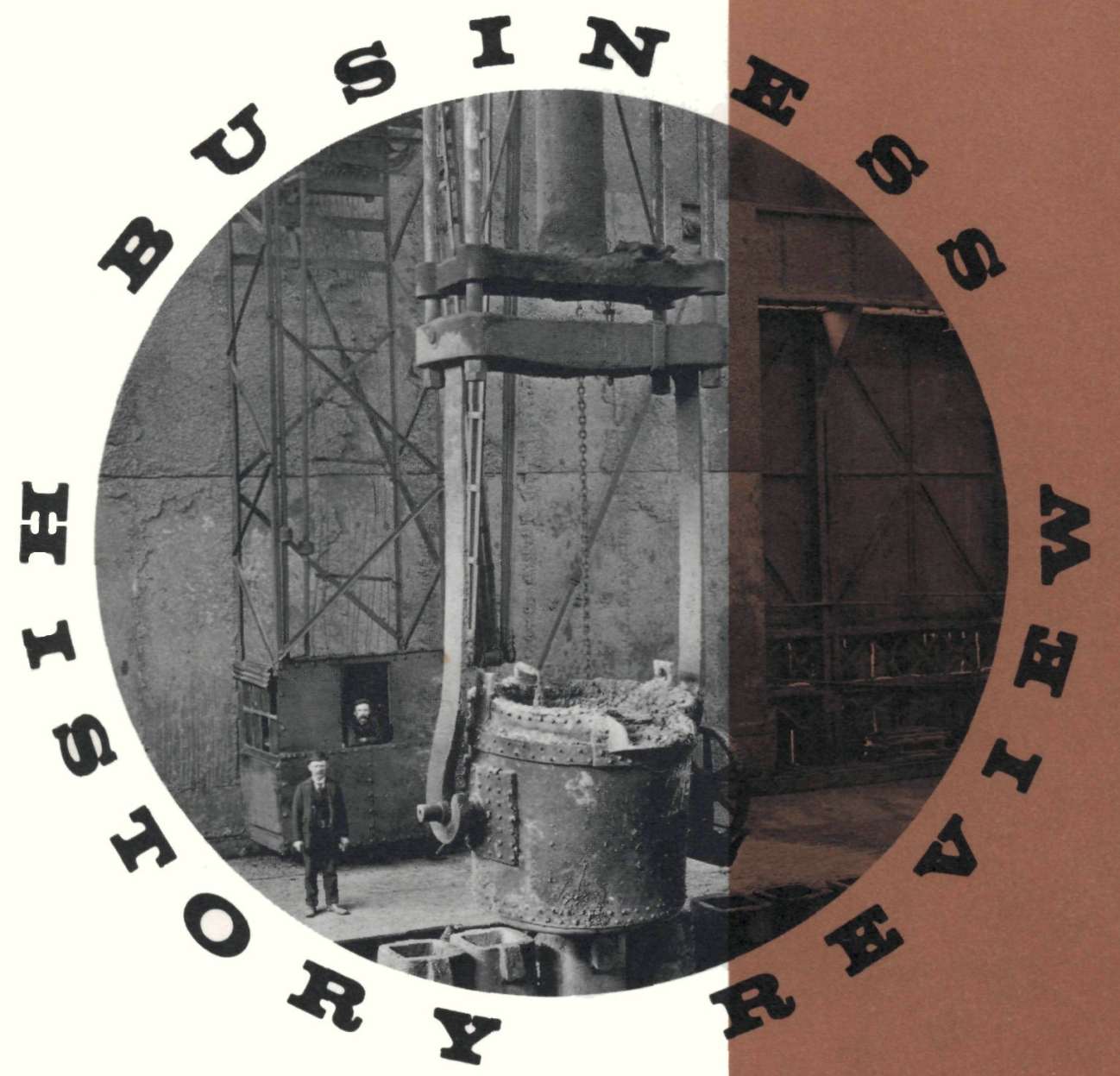

https://doi.org/10.1017/S0007680500028555 Published online by Cambridge University Press

PBLISHED BY THE HARVARD UNIVERSITY GRADUATE SCHOOL OF BUSINESS ADMINISTRATION 
ADVISORY BOARD

EDITOR

GLENN PORTER

Assistant Professor of Business History Harvard University
DEREK H. ALDCROFT

Professor of

Economic History

University of Leicester

FRED BATEMAN

Associate Professor of Business Economics

Indiana University

JAMES P. BAUGHMAN

Professor of

Business History

Harvard University

ALFRED D. CHANDLER, JR.

Straus Professor of

Business History

Harvard University

ROBERT D. CUFF

Associate Professor of History York University

ALFRED S. EICHNER

Associate Professor of Economics

State University of

New York, Purchase

STANLEX ENGERMAN

Professor of Economics

University of Rochester

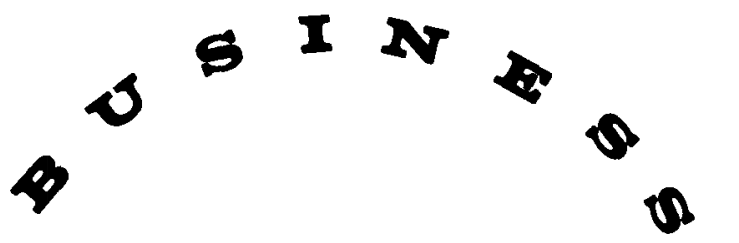

COVER: Interior view of Bessemer hydraulically operated crane, Bethlehem Steel, Maryland plant, 1909.

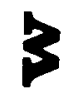

(1)

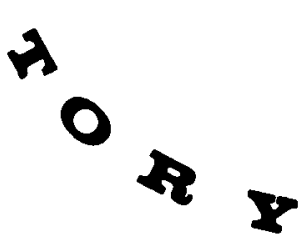

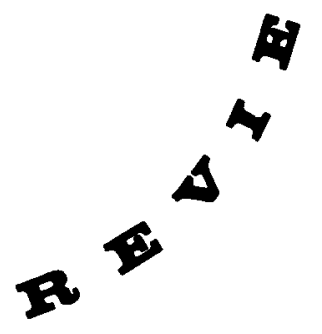

GEORGE GREEN

Associate Professor of History

University of Minnesota

GERALD N. GROB

Professor of History

Rutgers University

ELLIS W. HAWLEY

Professor of History

University of Iowa

RALPH W. HIDY

Professor of

Business History

Harvard University [Emeritus]

JURGEN KOCKA

Wissenschaftlicher Assistent in History

University of Münster

PETER Mathias

Chichele Professor of

Economic History

Oxford University

FRITZ REDLICH

Harvard University [retired]

HARRY N. SCHELBER

Professor of History

University of California, San Diego

MIRA WILKINS

Whately, Mass.

HAROLD D. WOODMAN

Professor of History

Purdue University

KOZO YAMAMURA

Professor of Economics

University of Washington

\section{HONORARY MEMBERS}

ARTHUR H. COLE

Professor of

Business Economics

Harvard University [Emeritus]

HENRIETTA M. LARSON

Professor of

Business History

Harvard University [Emerita] 


\section{B USINESS HISTORY REVIE W}
C
$\mathrm{O}$
N
T
$\mathrm{E}$
N T
$S$

TAXPAYERS OR INVESTORS: WHO PAID FOR THE LAND-GRANT RAILROADS?

LLOYD J. MERCER

AMERICAN WAR MOBILIZATION AND THE USE OF SMALL MANUFACTURERS, 1939-1943 . .

SCOTTISH RAILWAYS AND THE DEVELOPMENT OF SCOTTISH LOCOMOTIVE BUILDING IN THE NINETEENTH CENTURY WRAY VAMPLEW

THE TRANSFORMATION OF BETHLEHEM STEEL, 1904-1909 . ROBERT HESSEN

EDITOR'S CORNER

\section{BOOK REVIEWS}

Seaburg, Carl, and Stanley Paterson, Merchant Prince of Boston: Colonel T. H. Perkins, 1764-1854. Reviewed by Frank Carpenter . . . . . . . . . . . . . .

Whiteman, Maxwell, Copper for America: The Hendricks Family and a National Industry, 1755-1939. Reviewed by Irene D. Neu

Green, George D., Finance and Economic Development in the Old South: Louisiana Banking, 1804-1861. Reviewed by Roger S. White . . . • . . . . . . . . .

Athern, Robert G., Union Pacific Country. Reviewed by Albro Martin

Miner, H. Craig, The St. Louis-San Francisco Transcontinental Railroad: The Thirty-Fifth Parallel Project, 1853-1890. Reviewed by Albro Martin . . . . . . . . 


\section{$\begin{array}{llllllll}C & O & N & T & E & N & T & S\end{array}$}

(continued)

Wilson, Joan Hoff, American Business and Foreign Policy, 19201933. Reviewed by N. Stephen Kane. . . . . . .

Miller, Raymond C., The Force of Energy: A Business History of the Detroit Edison Company. Reviewed by Rosario J. Tosiello

Light, Ivan H., Ethnic Enterprise in America: Business and Welfare Among Chinese, Japanese, and Blacks. Reviewed by Thomas C. Cochran . . . . . . . . . .

Scheele, Carl H., A Short History of the Mail Service. Reviewed by Ross M. Robertson. . . . . . . . . . .

Douglass, Elisha P., The Coming of Age of American Business: Three Centuries of Enterprise, 1600-1900. Reviewed by Jack Blicksilver

Krooss, Herman E., and Charles Gilbert, American Business History. Reviewed by Harold F. Williamson . . . . .

Marris, Robin, and Adrian Wood, eds., The Corporate Economy: Growth, Competition and Innovative Potential. Reviewed by Herman Daems

Jackson, Gordon, Hull in the Eighteenth Century: A Study in Economic and Social History. Reviewed by Francis E. Hyde

Hyde, Francis E., Liverpool and the Mersey: An Economic History of a Port, 1700-1970. Reviewed by Baron F. Duckham .

Higgins, J. P. P., and Sidney Pollard, eds., Aspects of Capital Investment in Great Britain, 1750-1850. Reviewed by S. B. Saul

Lee, C. H., A Cotton Enterprise, 1795-1840: A History of M'Connel and Kennedy, Fine Cotton Spinners. Reviewed by Richard L. Hills.

Morton, Jocelyn, Three Generations in a Family Textile Firm. Reviewed by J. deL. Mann .

Leleux, Fernand, A L'Aube du Capitalisme et de la Revolution Industrielle: Lieven Bauwens Industriel Gantois. Reviewed by Herman Freudenberger . . . . . . . . .

O'Brien, D. P., ed., The Correspondence of Lord Overstone. Reviewed by Frank W. Fetter . . . . . . . . 


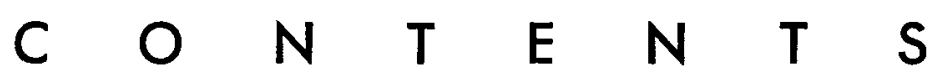

\section{(continued)}

McCloskey, Donald N., ed., Essays on a Mature Economy: Britain After 1840. Reviewed by B. R. Mitchell . . .

Udovitch, Abraham L., Partnership and Profit in Medieval Islam. Reviewed by Subhi Labib . . . . . . . . . .

Molho, Anthony, Florentine Public Finances in the Early Renaissance, 1400-1433. Reviewed by Richard A. Goldthwaite .

Nevaskar, Balwant, Capitalism without Capitalists: The Jains of India and the Quakers of the West. Reviewed by Ivan Light

Bagchi, Amiya Kumar, Private Investment in India, 1900-1939. Reviewed by Dwijendra Tripathi . . . . . . . .

Tandon, Prakash, Beyond Punjab: 1937-1960. Reviewed by Amiya Kumar Bagchi . . . . . . . . . . .

Weiss, Dimitri, La Communication dans les Organisations Industrielles: Contributions a L'Etude de la Presse d'Entreprise. Reviewed by James M. Laux . . . . . . . . .

Forster, Colin, ed., Australian Economic Development in the Twentieth Century. Reviewed by Alan Barnard. . . .

The Business Histony Review is published in the Spring, Summer, Autumn, and Winter. Address all communications, including manuscripts, change of address, and rights and permissions inquiries to Buseness History REviEw, 214-216 Baker Library, Soldiers Field, Boston, Massachusetts 02163. Telephone 617-495-6367. Regular subscription rate $\$ 10$ per year. Special rate for teachers and students $\$ 6$ per year. Single copies and reprints of most articles are available; information on request.

The BusIness History Review does not assume responsibility for statements of fact or opinion made by its contributors.

The Business History Review Five-Year Index: Volume XXXVI (1962) THROUGH Volume XL (1966) can be obtained from our editorial office at $\$ 3.00$, postpaid. The fifty-nine page guide provides detailed author, title, proper name, and subject entry to our articles, notes, and reviews over its period of coverage.

Contents are currently indexed or abstracted in: Accountants' Index; America: History and Life; Book Review Index; Book Review Index to Social Science Periodicals, Business Methods Index; Business Periodicals Index; Current Contents: Behavioral, Social, and Management Sciences; Historical Abstracts; Index to Economic Journals; Journal of Economic Literature; and Public Affairs Information Service Bulletin. Second-class postage paid at Boston, Massachusetts. Printed at Harvard University Printing Office.

Copyright $(1972$, by the President and Fellows of Harvard College. 